\title{
Preliminary observations on the age and growth of dog snapper (Lutjanus jocu) and mahogany snapper (Lutjanus mahogoni) from the Southeastern U. S.
}

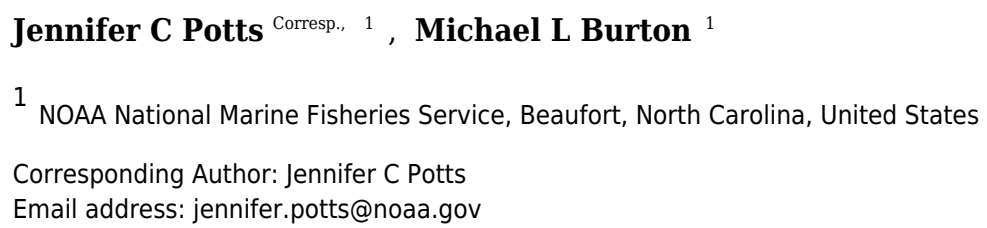

Dog snapper (Lutjanus jocu Bloch and Schneider 1801) and mahogany snapper (Lutjanus mahogoni Cuvier 1828) are infrequently caught snappers in the southeastern U.S. primarily occurring off of southern Florida. The species were opportunistically sampled from commercial and recreational fisheries in the southeastern U. S. from 1979 to 2015. Fish were aged ( 56 dog snapper and 54 mahogany snapper) by counting opaque zones on sectioned sagittal otoliths. Otoliths of both species were easily interpretable and agreement between readers was acceptable. Analysis of otolith edge-type revealed that annuli formed between May and July on both species. Dog snapper ranged from $200-837$ $\mathrm{mm}$ total length (TL) and ages 2 - 33, while mahogany snapper ranged from $270-416 \mathrm{~mm}$ $T L$ and ages $2-18$. The von Bertalanffy growth equations were $L_{t}=746\left(1-e^{(-0.20(t-0.32))}\right)$ and $L_{t}=334\left(1-e^{(0.31(t+1.19))}\right)$ for dog snapper and mahogany snapper, respectively. The weightlength relations were $\mathrm{W}=1.31 \times 10^{-5} \mathrm{~L}^{3.03}\left(n=78, r^{2}=0.99\right)$ and $\mathrm{W}=5.40 \times 10^{-6} \mathrm{~L}^{3.15}(n=$ $79, r^{2}=0.79$ ) for dog snapper and mahogany snapper, respectively, where $\mathrm{W}=$ whole weight in grams. 
3 Preliminary Observations on the Age and Growth of Dog Snapper (Lutjanus jocu) and

4 Mahogany Snapper (Lutjanus mahogoni) from the Southeastern U. S.

9 Running Head: Age-Growth of Dog Snapper and Mahogany Snapper

11 NOAA/National Marine Fisheries Service, 101 Pivers Island Rd., Beaufort, North

12 Carolina 28516-9722.

13 <Jennifer.Potts@noaa.gov>

14

15 Keywords: age-growth, dog snapper, mahogany snapper, edge-type analysis.

16 
ABSTRACT

26 Dog snapper (Lutjanus jocu Bloch and Schneider 1801) and mahogany snapper (Lutjanus

27 mahogoni Cuvier 1828) are infrequently caught snappers in the southeastern U.S.

28 primarily occurring off of southern Florida. The species were opportunistically sampled

29 from commercial and recreational fisheries in the southeastern U. S. from 1979 to 2015.

30 Fish were aged (56 dog snapper and 54 mahogany snapper) by counting opaque zones on

31 sectioned sagittal otoliths. Otoliths of both species were easily interpretable and

32 agreement between readers was acceptable. Analysis of otolith edge-type revealed that

33 annuli formed between May and July on both species. Dog snapper ranged from 200 -

$34837 \mathrm{~mm}$ total length (TL) and ages $2-33$, while mahogany snapper ranged from $270-$

$35416 \mathrm{~mm}$ TL and ages $2-18$. The von Bertalanffy growth equations were $\mathrm{L}_{\mathrm{t}}=746\left(1-\mathrm{e}^{(-}\right.$

$36 \quad 0.20(\mathrm{t}-0.32))$ and $\mathrm{L}_{\mathrm{t}}=334\left(1-\mathrm{e}^{(0.31(\mathrm{t}+1.19))}\right)$ for dog snapper and mahogany snapper,

37 respectively. The weight-length relations were $\mathrm{W}=1.31 \times 10^{-5} \mathrm{~L}^{3.03}\left(n=78, r^{2}=0.99\right)$

38 and $\mathrm{W}=5.40 \times 10^{-6} \mathrm{~L}^{3.15}\left(n=79, r^{2}=0.79\right)$ for dog snapper and mahogany snapper,

39 respectively, where $\mathrm{W}=$ whole weight in grams.

\section{INTRODUCTION}

45 The dog snapper, Lutjanus jocu (Bloch \& Schneider, 1801) is a moderate- to large-

46 sized snapper (Lutjanidae) occurring infrequently in commercial and recreational reef 
47 fish catches in the southeastern U. S. (SEUS), which includes North Carolina south

48 through the Florida Keys. The species is distributed in the western Atlantic Ocean from

49 North Carolina to Brazil, into the Gulf of Mexico and throughout the Caribbean Sea,

50 though they are rare north of Florida (Carpenter, 2002). Dog snapper have also been

51 reported from the eastern Atlantic at Ascension Island (Lubbock, 1980) and from the

52 Mediterranean Sea (Vacchi et al., 2010). The mahogany snapper, Lutjanus mahogoni

53 (Cuvier, 1828), a smaller member of the Lutjanidae also caught infrequently by fishers, is

54 distributed in the western Atlantic Ocean from the Carolinas to Venezuela and throughout

55 the Caribbean Sea, including the Gulf of Mexico (Carpenter, 2002). Both species are

56 found on coral reefs and rocky hardbottom habitat at depths up to $100 \mathrm{~m}$. Mahogany

57 snapper are known to form large social aggregations (McEachran \& Fechhelm, 2005),

58 while dog snapper are typically solitary and wary except when in spawning aggregations

59 (Domeier, Koenig \& Coleman, 1996).

61 Both species are of limited importance to the SEUS reef fish fishery, and the sparse

62 estimated landings for both species reflect their low occurrence in the SEUS region

63 (Table 1). Also, these less frequently landed snappers tend to be lumped into a

64 "unclassified snappers" category in recreational and commercial landings reporting, thus

65 making more definitive species-specific landings discrimination difficult. Few or zero

66 intercepts of the species by port agents did not allow the two separate recreational

67 surveys, Southeast Region Headboat Survey (SRHS) and Marine Recreational Intercept

68 Program (MRIP), to estimate landings by weight, thus landings were only recorded by

69 number of fish landed. In the SEUS, recreational fisheries landings were estimated at an 
70 average of 1236 dog snapper and 1122 mahogany snapper per year from $1981-2015$

71 (NMFS 2016a). On the other hand, commercial landings were reported by weight, not

72 numbers of fish. Average commercial landings were $490 \mathrm{~kg}$ per year from $1991-2014$

73 for $L$. jocu, while commercial landings of L. mahogoni were virtually non-existent (79 $\mathrm{kg}$

74 total from 1986-2014) (NMFS 2016b). Dog snapper landings in the U. S. Caribbean

75 (Puerto Rico and the U. S. Virgin Islands - USVI) were higher, with recreational

76 landings averaging 7227 fish annually between 2000 - 2015 (NMFS, 2016a) and

77 commercial landings averaging $120 \mathrm{~kg}$ per year from 1988 - 2012 (NMFS, 2016b).

78 Recreational landings of mahogany snapper from the U. S. Caribbean averaged 669 fish

79 annually from 2000 - 2015 (NMFS 2016a) while commercial landings averaged $173 \mathrm{~kg}$

80 per year from 1988 - 2012 (D. Gloeckner, SEFSC, NMFS, Miami FL, 2015).

82 Published studies on the life history of $L$. jocu are limited to age and growth studies

83 from Brazil (Rezende \& Ferreira, 2004; Previero et al., 2011) and Cuba (Claro, Sierra \&

84 Garcia-Arteaga, 1999), the documentation of spawning aggregations from Belize (Carter

$85 \&$ Perrine, 1994; Heyman et al., 2001) and the USVI (Kadison et al., 2006; Biggs \&

86 Nemeth, 2016), and habitat use by juveniles through adults on the Abrolhos Shelf of

87 Brazil (Moura et al., 2011). Franca \& Olavo (2015) examined commercial fishery

88 landings data from northeastern Brazil as indirect evidence for the presence of spawning

89 aggregations of dog snapper. Aschenbrenner, Hackradt \& Ferreira (2016) examined

90 habitat selection in early life history stages of dog snapper in northeastern Brazil. Studies

91 of L. mahogoni are limited to examinations of the importance of various habitat types in

92 Caribbean bays to juvenile stages (Nagelkerken et al., 2000a, Nagelkerken et al., 2000b). 
94 We studied these two species from the SEUS because little is known of their life

95 history, which is important to managers interested in multi-species or ecosystem-based

96 management. Both species were managed by the South Atlantic Fishery Management

97 Council (SAFMC) under the Snapper-Grouper Fishery Management Plan (FMP) from

981983 until June 22, 2016. At that time, the SAFMC made the decision to relegate

99 management of these species and several others to individual state resource agencies due

100 to the low magnitude of landings in federal waters. The species are currently managed by

101 the Florida Fish and Wildlife Conservation Commission (FWCC) with a 12-inch (305

$102 \mathrm{~mm}$ ) total length (TL) size limit and inclusion in a 10 snapper per person daily aggregate

103 bag limit (FWCC, 2016). Increasing restrictions on more commonly caught reef fish

104 species will likely lead to increased harvest of less common species such as dog snapper

105 or mahogany snapper. Managers need to understand the growth of a species, since that

106 can be used to estimate its reproductive potential and mortality rate. To that end, we used

107 sectioned otoliths to determine ages of dog snapper and mahogany snapper from the

108 SEUS and to estimate seasonality of annulus formation. We also derived theoretical

109 growth parameters and determined length-length and weight-length relationships.

METHODS

112 Age estimation and timing of opaque zone formation. - Dog snapper and mahogany

113 snapper were opportunistically sampled from fisheries operating offshore of North

114 Carolina through Key West, FL. All specimens used in this study were killed as part of

115 legal fishing operations and were already dead when sampled by the port agents; thus all

116 research was conducted in accordance with the Animal Welfare Act (AWA) and with the 
117 US Government Principles for the Utilization and Care of Vertebrate Animals Used in

118 Testing, Research, and Training (USGP) OSTP CFR, May 20, 1985, Vol. 50, No. 97. All

119 fish were captured by either conventional vertical hook and line gear or by spears.

120 Sagittal otoliths were collected from 62 dog snapper and 57 mahogany snapper by

121 National Marine Fisheries Service port agents sampling the recreational headboat and

122 commercial fisheries from 1979 to 2015. Total (TL) and fork lengths (FL) of specimens

123 were recorded in millimeters $(\mathrm{mm})$, and whole weight was recorded in grams $(\mathrm{g})$ for fish

124 sampled by the Southeast Region Headboat Survey (SRHS). Weights were generally

125 unavailable for fish landed by the commercial fisheries, as these fish were eviscerated at

126 sea. Sagittal otoliths were removed through the otic bulla inside the gill cavity and stored

127 dry in coin envelopes. Otoliths were sectioned on a low-speed saw, following the

128 methods of Potts \& Manooch (1995). Three serial $0.5 \mathrm{~mm}$ sections were taken, with at

129 least one of them encompassing the otolith core. The sections were mounted on

130 microscope slides with thermal cement and covered with histological mounting medium

131 before analysis. The sections were viewed under a dissecting microscope at $12.5 \mathrm{X}$ using

132 reflected light (Fig. 1). Each sample was assigned an opaque zone count by two readers.

133 Counts were compared between readers. An index of average percent error (APE) was

134 calculated, following the methodology of Beamish \& Fournier (1981). Where two

135 readings for a specimen disagreed, the sections were viewed again. If agreement was

136 reached the sample was retained; otherwise, the sample was discarded from further

137 analysis.

138 
140 visual categorization. The edge type of the otolith was noted: 1 = opaque zone forming on

141 the edge of the otolith section; 2 = narrow translucent zone on the edge, generally less

142 than $30 \%$ of the previous translucent zone; $3=$ moderate translucent zone on the edge,

143 generally $30 \%$ to $60 \%$ of the previous translucent zone; $4=$ wide translucent zone on the

144 edge, generally greater than $60 \%$ of the previous translucent zone (Harris et al., 2007).

145 All samples were assigned an age based on edge frequency analysis metrics, opaque zone

146 count and time of capture. The zone count was increased by one, to reflect the calendar

147 age of the fish, if the specimen was caught before increment formation and had an edge

148 that was a moderate to wide translucent zone (type 3 or 4).

150 Theoretical Growth. - Von Bertalanffy (1938) growth parameters were estimated from

151 the observed length-at-age data. Calendar age was used since little information on

152 reproduction of these species in U. S. waters was available to assign a biological age.

153 Growth parameters were derived initially by minimizing the negative sum of log-

154 likelihoods with the AD Model Builder estimation software (Otter Research Ltd., Sidney,

155 B.C., Canada). We examined parameters computed from a freely-estimated model,

156 assuming normal distribution of lengths about each calendar age, and a model that

157 adjusted for size selectivity bias within the fishery. Because samples for this study were

158 obtained from fishery landings, the estimate of growth at the youngest ages may be

159 skewed due to minimum size regulations imposed on the fishery or selection of the fish

160 by the fishers. As an alternate strategy to model growth, the von Bertalanffy growth

161 parameters were estimated using a left-truncated normal probability density function on 
162 length for fish subjected to the minimum size limit (305 $\mathrm{mm} \mathrm{TL}$ ) regulation, as developed

163 by McGarvey \& Fowler (2002). For samples in this study not subject to minimum size

164 limit, the full, untruncated normal likelihood was used.

165

166 Body Size relationships. - Important metrics of fish species include the relationship

167 between weight and length and between various length measurements. Whole fish

168 weight (g) was regressed on TL using data for all dog snapper and mahogany snapper

169 measured by the SRHS from $1979-2015$ ( $n=78$, L. jocu; $n=79$, L. mahogoni $)$. We

170 evaluated both direct fits using nonlinear least squares regression (SAS Institute, 1987)

171 and a linearized fit of the log-transformed data, examining the residuals to determine

172 which fit was more appropriate. We used the same SRHS data to examine the

173 relationships between TL and FL using linear regression $(n=48$, dog snapper; $n=65$,

174 mahogany snapper).

175

RESULTS

177 Age Estimation. - A total of 56 sagittal otoliths from L. jocu were sectioned (six otoliths

178 were broken in storage). Fifty-four otoliths from L. mahogoni were sectioned, (three were

179 broken in storage). The distribution by fishery and state of age samples is shown in Table

180 2. Dog snapper samples were primarily from southeastern Florida and Florida Keys

181 waters (25 from commercial fishery landings and 25 from headboat angler landings) but

182 did include five samples from the North Carolina commercial fishery and one sample

183 from the South Carolina commercial fishery. All mahogany snapper came from

184 southeastern Florida and Florida Keys waters, with $80 \%$ coming from recreational

185 headboat fisheries and 20\% coming from commercial landings. 
187 Sectioned otoliths for both species were clear and easy to interpret (Fig. 1). Opaque 188 zones were counted on all sectioned otoliths. Initial readings by the two authors resulted

189 in $61 \%$ and $69 \%$ agreement for dog snapper and mahogany snapper, respectively. When

190 we used \pm 1 year, agreement increased to $95 \%$ and $98 \%$ respectively. APE was $3.29 \%$ for

191 dog snapper and $1.80 \%$ for mahogany snapper. These were both well within the criteria

192 of 5\% determined acceptable by Campana (2001). The age readers reviewed the samples

193 where there was disagreement on the age and were able to reach consensus. Thus, all age

194 data were used in subsequent analysis.

195

196 Timing of opaque zone formation. - Opaque zones on the otolith marginal edge

197 occurred May through July for both species (Fig. 2). Otoliths from dog snapper were

198 without an opaque zone on the edge from August through April, while a single mahogany

199 snapper caught in November exhibited an opaque edge. Dog snapper exhibited the least

200 amount of translucent edge from August through October, with the width of the

201 translucent edge increasing until reaching a maximum January through April, prior to

202 opaque zone deposition in May. Mahogany snapper exhibited a similar pattern. We

203 concluded that opaque zones on otoliths of both species were annuli.

204

205 We assigned calendar, or chronological, ages as follows: for fish caught January

206 through July and having an edge type of 3 or 4, the annuli count was increased by one;

207 for fish caught in that same time period with an edge type of 1 or 2 and for fish caught

208 from August to December, the calendar age was equivalent to the annuli count. 
210 Growth. - Dog snapper in this study ranged from 200 - $836 \mathrm{~mm}$ TL and from ages 2 -

21133 , but only four fish were older than age-12 (Table 3). While 50 out of 57 fish (88\%)

212 were from Florida, the largest and oldest fish was from South Carolina. Predicted size-at-

213 age of dog snapper agreed well with mean observed size-at-age (Fig. 3a). The von

214 Bertalanffy parameters ( \pm 1 Std. Err.) are presented in Table 4. The growth model

215 parameters estimated when correcting for the left-truncated normal distribution imposed

216 by the minimum size limit regulation (McGarvey \& Fowler, 2002) are also in Table 4.

217 The model appeared to have a more realistic estimate of initial growth (Fig. 3a; Table 4).

218 Comparing negative log likelihood values from each model, the model incorporating the

219 correction for the truncated normal distribution due to the size limit regulation was a

220 better fit to the data than when assuming no bias (-log likelihood: 294.65 v. 343.95).

221 Mahogany snapper ranged from $270-416 \mathrm{~mm}$ and ages $2-18$. All samples were

222 from south Florida waters. Predicted size-at-age for the freely estimated model run

223 agreed reasonably well with mean observed size-at-age (Fig. 3b), and the von Bertalanffy

224 parameters ( \pm 1 Std. Err.) are presented in Table 4. As with dog snapper, the mahogany

225 snapper specimens available for this study lacked smaller fish due to the fishery-

226 dependent nature of the samples; the resulting growth parameters using the method of

227 McGarvey \& Fowler (2002) are in Table 4 and graphically presented in Fig. 3b. As

228 with dog snapper, the model assuming the truncated normal distribution on lengths at the

229 youngest ages was a better fit to the data than the freely estimated model (-log likelihood:

$230 \quad 222.85$ v. 245.57). 
232 Weight-Length relations. - When performing the statistical analyses of W-L relations, a

233 multiplicative error term (variance increasing with size) in the residuals was revealed for

234 both dog and mahogany snappers. A linearized ln-transform fit of the data was

235 appropriate, and the resulting equations were:

$$
\text { Dog snapper }-\operatorname{Ln}(\mathrm{W})=3.028 \ln (\mathrm{L})-11.249 ;\left(n=78, r^{2}=0.99\right)
$$

$$
\text { Mahogany snapper }-\operatorname{Ln}(\mathrm{W})=3.154 \ln (\mathrm{L})-12.136 ;\left(n=79, r^{2}=0.79\right)
$$

238 where $\mathrm{W}=$ whole weight in grams and $\mathrm{L}=$ total length in $\mathrm{mm}$. The equations were

239 transformed back to the power equation form, $\mathrm{W}=\mathrm{a} \mathrm{L}^{\mathrm{b}}$, after adjusting the intercepts for

240 log-transformation bias with the addition of one-half of the mean-square error (1/2 MSE)

241 (Beauchamp and Olson 1973). The resulting regression equations were:

244 Length-Length relations. - The relationships between TL and FL as determined by linear 245 regression are described by the following equations:

Dog snapper: $\mathrm{TL}=1.05 \mathrm{FL}+6.40\left(n=48, r^{2}=0.99\right)$

$$
\mathrm{FL}=0.95 \mathrm{TL}-5.17\left(n=48, r^{2}=0.99\right)
$$

Mahogany snapper: $\mathrm{TL}=1.03 \mathrm{FL}+9.27\left(n=65, r^{2}=0.93\right)$

$$
\mathrm{FL}=0.89 \mathrm{TL}+12.01\left(n=65, r^{2}=0.93\right)
$$

\section{DISCUSSION}

252 Opaque zones in the otoliths of both dog snapper and mahogany snapper were

253 determined to be deposited once per year between May and July. Other SEUS lutjanids

254 display similar timing of annulus deposition. Gray snapper (Lutjanus griseus Linnaeus, 255 1758) deposited annuli in June and July (Burton, 2001), and mutton snapper (Lutjanus 
256 analis Cuvier 1828) deposited annual rings from March to May (Burton, 2002). Cubera

257 snapper (Lutjanus cyanopterus Cuvier, 1828) were found to deposit annuli from April to

258 August, peaking in May and June (Burton and Potts, 2017).

259 Like many Lutjanus spp., dog snapper grew reasonably fast, attaining an average

260 observed size of $322 \mathrm{~mm}, 491 \mathrm{~mm}, 585 \mathrm{~mm}, 704 \mathrm{~mm}$ and $755 \mathrm{~mm}$ by ages 3, 5, 7, 10 and

26113 respectively (Table 3, Fig. 3a). The predicted growth curve from the freely-estimated

262 growth model fit the observed data well and could be used to describe fish recruited to

263 the fishery. Due to the minimum size limit regulations, the smallest and youngest fish

264 were excluded from the fishery landings, and these regulations have the effect of

265 capturing the fastest growers at the youngest ages retained in the fishery landings.

266 Because of this selectivity, the freely estimated model can represent growth of fish in the

267 fishery, but over-estimated initial growth of the fish in the population. The use of the size

268 limit bias corrected growth model has become standard practice in U.S. Southeast Data,

269 Assessment and Review (SEDAR) stock assessments since 2005 (starting with SEDAR,

270 2005). In the case of yellowmouth grouper (Mycteroperca interstitialis) where no fish in

271 the study was younger than age-3, the use of the bias-corrected model yielded a more

272 biologically reasonable growth model (Burton, Potts \& Carr, 2014). We feel the

273 correction to the dog snapper growth model imposed by the bias in selectivity of the fish

274 in the fishery more accurately estimates the growth of the fish in the population (Fig. 3a).

275 Growth parameters and associated standard errors for both model runs are given in Table 2764.

277 
278 While this study is the first to examine growth of dog snapper from SEUS waters, other

279 studies from the Caribbean found similar parameters (Table 4). Rezende \& Ferreria

280 (2004) estimated $L_{\infty}$ close to what we estimated in our study, but the $K$ and $t_{0}$ values were

281 very different. Because of the much larger negative $t_{0}$ in their study, initial growth of the

282 fish was not biologically reasonable, which in turn under-estimated $K$. In the case of

283 Claro, Sierra \& Gracia-Arteaga (1999) and Previero et al. (2011), the $t_{0}$ values they

284 present approached what we estimated. The $L_{\infty}$ values were much higher, though, and

285 with the inverse correlation of $L_{\infty}$ to $K$, the $K$ values from those studies were lower than

286 ours. Red snapper (L. campechanus), a close congener and co-occurring species, also

287 show fast initial growth $(K=0.24$; SEDAR, 2016) attaining asymptotic length relatively

288 quickly compared to some other large reef fish species. We feel that more attention

289 should be given to estimating fish growth.

291 The oldest dog snapper in our study was 33 yr old and was caught in the South

292 Carolina commercial fishery. The vast majority of dog snapper samples came from

293 Florida waters, where the oldest fish was $22 \mathrm{yr}$ old. The studies by Rezende \& Ferreria

294 (2004) and Previero et al. (2011) demonstrated that the species certainly has a longevity

295 beyond what we found from Florida fish. From the limited data on depth of fishing

296 associated with the dog snapper samples $(15-73 \mathrm{~m})$, our oldest fish was caught in the

297 deepest water recorded (73 m), which supports the findings of Moura et al. (2011) that

298 dog snapper perform cross shelf ontogenetic migrations from inshore to offshore as they

299 get older. We would expect the oldest and largest fish to be caught from deeper offshore

300 habitats. 
Mahogany snapper are a smaller, shorter-lived fish than dog snapper, and as such

302 exhibit a much smaller length distribution, with maximum TL just over $400 \mathrm{~mm}$. The

303 mean observed length-at-age data fits the growth curve fairly well, but because of lack of

304 age-1 fish and the paucity of samples for all ages below age-5, it does not do a good job

305 of describing the growth of the early part of the growth trajectory. For this reason, we

306 modeled growth using the bias-corrected model of McGarvey \& Fowler (2002). This

307 model had little effect on the estimates for the parameters $L_{\infty}, K$ increased slightly, but

308 resulted in a change in the value of $t_{0}$ from -4.18 to a more biologically realistic value of -

3091.19 (Table 4). This value resulted in a theoretical size-at-age for mahogany snapper of

$310104 \mathrm{~mm}$ at age- $0,165 \mathrm{~mm}$ at age-1, and $210 \mathrm{~mm}$ at age-2.

311 Though the number of samples for this study were limited, we have seen similar

312 patterns of growth in other species in the genus Lutjanus in the SEUS. Dog snapper is

313 one of the larger Lutjanids and exhibits similar fishery growth parameters to mutton

314 snapper, L. analis (Burton, 2002). The growth coefficients $(K)$ of both species, 0.15 for

315 dog snapper and 0.16 for mutton snapper (Burton, 2002), indicate that both species take

316 longer time to reach their maximum size, compared to smaller snapper species). The fact

317 that we found a 33 yr old dog snapper within so few age samples suggests that their

318 longevity could approach that of mutton snapper (up to 40 years; SEDAR, 2015). The

319 adults of both species have been described as generally solitary and wary except at the

320 time of aggregating to spawn (Domeier, Koenig \& Coleman, 1996). On the other hand,

321 mahogany snapper is one of the smallest Lutjanus species, and more similar to lane

322 snapper, L. synagris, in growth and behavior. Brennan (2004) estimated the von

323 Bertalanffy growth parameters for lane snapper from the commercial and recreational 
324 fisheries of southeast Florida similar to the age samples we had available for this study.

325 Both mahogany snapper and lane snapper attain their maximum size more rapidly than

326 their larger congeners and do not tend to live as long $-K=0.31$ and max age $=18$ years

327 for mahogany snapper and $K=0.34$ and $\max$ age $=12$ years for lane snapper. Also, these

328 smaller lutjanids form social aggregations during the day. The similarities within groups

329 of lutjanids could allow managers to make predictions on fishery impacts to the less

330 common species based on behavior and growth patterns of more well studied species.

331 We have demonstrated in this study that sectioned sagittal otoliths are an effective

332 method for the aging of dog snapper and mahogany snapper. We have presented the first

333 description of life history parameters for these two species for samples from SEUS

334 waters and the first description in the literature for mahogany snapper age and growth.

335 While the magnitude of landings from mainland SEUS waters for both species is low,

336 they are of more importance in the U. S. Caribbean and these studies could contribute to

337 effective management in these locales. Another equally important reason for studying

338 species for which we have little information is that eventually this information is likely to

339 be needed for inclusion in multispecies stock assessments or ecosystem-based assessment

340 models (Christensen et al., 2009).

341

ACKNOWLEDGMENTS

343 We extend thanks to all the NMFS and state port agents who collected otoliths from

344 commercial and headboat fisheries for this study. Thanks are also due to Vivian Matter

345 and David Gloeckner of the Miami NMFS lab for supplying Caribbean landings data,

346 Tom Sminkey from the NMFS Office of Science and Technology, Silver Spring MD for 
347 supplying recreational landings data. Thanks to Rob Cheshire, Nate Bacheler, and

$348 \mathrm{XXXXXX}$ for initial reviews of this manuscript, as well as the other anonymous

349 reviewers that made this manuscript stronger.

350

LITERATURE CITED

353 Aschenbrenner A, Hackradt CW, Ferreira BP. 2016. Spatial variation in density and size

354 structure indicate habitat selection throughout life stages of two Southwestern

355 Atlantic snappers. Marine Environmental Research. 113: 49-55.

357 Beamish RJ, Fournier DA. 1981. A method for comparing the precision of a set of age determinations. Canadian Journal of Fisheries and Aquatic Sciences. 38:982-983.

360 Beauchamp JJ, Olson JS. 1973. Corrections for bias in regression estimates after logarithmic transformations. Ecology 54: 1403-1407.

363 Biggs CR, Nemeth RS. 2016. Spatial and temporal movement patterns of two snapper 364 species at a multi-species spawning aggregation. Marine Ecology Progress Series 558:129-142.

367 Brennan KJ. 2004 Age, growth and mortality of lane snapper, Lutjanus synagris, from

368 the east coast of Florida. M.S. Thesis. East Carolina University, Greenville, NC. $369 \quad 59 \mathrm{p}$. 
371 Burton ML. 2001. Age, growth, and mortality of gray snapper, Lutjanus griseus, from 372 the east coast of Florida. Fishery Bulletin 99:254-265.

373

374 Burton ML. 2002. Age, growth, and mortality of mutton snapper, Lutjanus analis, from

375 the east coast of Florida, with a brief discussion of management implications.

$376 \quad$ Fisheries Research 59:31-41.

378 Burton, ML, Potts, JC, Carr, DR. 2014. Age, growth, and mortality of yellowmouth grouper from the southeastern United States. Marine and Coastal Fisheries: Dynamics, Management, and Ecosystem Science 6:33-42.

382 Burton, ML, Potts JC. 2017. Age, growth and natural mortlity of cubera snapper Lutjanus cyanopterus from the southeastern United States, Bulletin of Marine Science, https://doi.org/10.5343/bms.2016.1116

386 Campana SE. 2001. Accuracy, precision and quality control in age determination, 387 including a review of the use and abuse of age validation methods. Journal of Fish Biology 59:197- 242.

390 Carpenter, K.E. (ed.). 2002. The living marine resources of the Western Central Atlantic. Volume 3: Bony fishes part 2 (Opistognathidae to Molidae), sea turtles and marine mammals. FAO Species Identification Guide for Fishery Purposes and 
American Society of Ichthyologists and Herpetologists Special Publication No. 5.

396 Carter J, Perrine D. 1994. A spawning aggregation of dog snapper, Lutjanus jocu (Pisces:Lutjanidae) in Belize, Central America). Bulletin of Marine Science $55: 228-234$.

Christensen V, Walters CJ, Ahrens R, Alder J, Buszowski J, Christensen LB, Cheung WWL, Dunne J, Froese R, Karpouzi V. 2009. Database-driven models of the world's large marine ecosystems. Ecological Modelling 220:1987-1996.

404 Claro R, Sierra LM, Garcia-Arteaga JP. 1999. Biologia del jocu, Lutjanus jocu (Pisces: Lutjanidae) en las NE y SW de la plataforma Cubana. II. Alimentacion, edad y

408 Domeier ML, Koenig C and Coleman F. 1996. Reproductive biology of gray snapper (Lutjanus grieseus) with notes on spawning for other western Atlantic snappers

410 (Lutjanidae). In Biology and culture of tropical groupers and snappers (F. 
415 Franco AR, Olavo G. 2015. Indirect signals of spawning aggregations of three

416 commercial reef fish species on the continental shelf of Bahia, east coast of

417 Brazil. Brazilian Journal of Oceanography 63:289-302.

418

419 FWCC 2016. Florida Fish and Wildlife Conservation Commission. Snapper Rules and $420 \quad$ Regulations. Available at www.myfwc.com/fishing/saltwater/recreational/snappers (Accessed October 26,2016).

424 Harris PJ, Wyanski DM, White DB, Mikell PP, Eyo PB. 2007. Age, growth and 425 reproduction of greater amberjack off the southeastern US Atlantic coast. 426 Transactions of the American Fisheries Society 136:1534-1545.

428 Heyman WD, Graham RT, Kjerfve B, Johannes R. 2001. Whale sharks Rhincodon typus 429 aggregate to feed on fish spawn in Belize. Marine Ecology Progress Series $430 \quad 215: 275-282$.

432 Kadison,E, Nemeth RS, Herzlieb S, Blondeau J. 2006. Temporal and spatial dynamics of 433 Lutjanus cyanopterus (Pisces:Lutjanidae) and L. jocu spawning aggregations in 434 the United States Virgin Islands. Revista de Biologia. Tropical 54:69-78.

435

436 Lubbock R. 1980. The shore fishes of Ascension Island. Journal of Fish Biology 17: 437 283-303. 
439 McEachran JD, Fechhelm JD. 2005. Lutjanidae:Snappers. In: McEachran JD, Fechhelm

440 JD, editors. Fishes of the Gulf of Mexico. Volume 2: Scorpaeniformes to

441 Tetraodontiformes. Austin Texas. University of Texas Press. P. 317-337.

443 McGarvey R, Fowler AJ. 2002. Seasonal growth of King George whiting (Sillaginodes 444 punctata) estimated from length-at-age samples from the legal-size harvest.

$445 \quad$ Fishery Bulletin 100:545-558.

447 Moura RL, Francini-Filho RB, Caves EM, Minte-Mera CV, Lindeman KC. 2011. Use of 448 reiverine through reef habiat sytems by dog snapper (Lutjanus jocu) in eastern 449 Brazil. Estuarine Coastal Shelf Science 95:274-278.

451 Nagelkerken I, Dorenbosch, WE, Verberk CP, Cocheret de la Moriniere E, van der Velde

452 G. 2000a. Importance of shallow water biotopes of a Caribbean bay for juvenile 453 coral reef fishes: patterns in biotope association, community structure and spatial 454 distribution. Marine Ecology Progress Series 202: 175-192.

456 Nagelkerken, I, van der Velde G, Gorissen W,. Meijer GJ, van’t Hof T, den Hartog C.

457 2000b. Importance of mangroves, seagrass beds and the shallow coral reef as a 458 nursery for important coral reef fishes, using a visual census technique. Estuarine $459 \quad$ Coastal Shelf Science 51: 31-44. 
461 NMFS 2016a. NOAA Office of Science and Technology, Recreational Fisheries

462 Statistics Queries. https://www.st.nmfs.noaa.gov/st1/recreational/queries

463 (Accessed October 26, 2016).

464

465 NMFS 2016b. NOAA Office of Science and Technology, Commercial Fisheries

466 Statistics, Annual Commercial Landings Statistics.

467 https://www.st.nmfs.noaa.gov/st1/commercial/landings/annual landings.html

468 (Accessed October 26, 2016).

469

470 Potts JC, Manooch CS III. 1995. Age and growth of red hind and rock hind collected

471 from North Carolina through the Dry Tortugas, Florida. Bulletin of Marine

$472 \quad$ Science 56: 784-794.

473

474 Potts JC, Manooch CS III. 2001. Differences in the age and growth of white grunt from 475 North Carolina and South Carolina versus southern Florida. Bulletin of Marine $476 \quad$ Science 68:1-12.

478 Previero MC, Minte-Mera V, Freitas MO, de Moura RL, Tos CD. 2011. Age and growth 479 of the dog snapper Lutjanus jocu (Bloch and Schneider 1801) in Abrolhos Bank, $480 \quad$ Northeastern Brazil. Neotropical Ichthyology 9:393-401. 
482 Rezende S. de Magalhaes, Ferreira BP. 2004. Age, growth and mortality of dog snapper

483 Lutjanus jocu (Bloch and Schneider, 1801) in the northeast coast of Brazil.

484 Brazilian Journal of Oceanography. 52:107-121.

485

486 SEDAR. 2005. SEDAR7: Stock assessment report of SEDAR7: Gulf of Mexico red

487 snapper. Available from http://sedarweb.org/docs/sar/S7SAR_FINAL-

$488 \quad$ redsnapper.pdf (accessed 28 February 2017).

489

490 SEDAR. 2015. SEDAR15a Update Assessment: Stock assessment of mutton snapper

491 (Lutjanus analis) of the U. S. South Atlantic and Gulf of Mexico through 2013,

$492 \quad$ Available from

493 http://sedarweb.org/docs/suar/SEDAR\%20Update\%20Stock\%20Assessment $\% 20$

494 of\%20Mutton\%20Snapper\%202015_FINAL.pdf (accessed 14 November 2016).

495

496 SEDAR. 2016. SEDAR41: South Atlantic red snapper assessment report. Available from

497 http://sedarweb.org/docs/sar/S41_SA_RS_SAR_Final 4.19.2016.pdf (accessed

498 28 February 207).

499

500 Vacchi M, Psomadakis PN, Repetto N, Würtz M. 2010. First record of dog snapper

501 Lutjanus jocu in the Mediterranean Sea. Journal of Fish Biology 76:723-728.

502

503 von Bertalanffy L. 1938. A quantitative theory of organic growth. Human Biology 10:

504 181-243. 
505 Table 1. Reported fisheries landings for dog snapper and mahogany snapper from the

506 SEUS and U.S. Caribbean, 1981-2015. SRHS = Southeast Region Headboat Survey;

507 MRIP $=$ Marine Recreational Intercept Program; Comm $=$ Commercial statistics.

\begin{tabular}{|c|c|c|c|c|c|c|c|c|c|c|}
\hline \multirow{3}{*}{ Year } & \multicolumn{5}{|c|}{ Dog Snapper } & \multicolumn{5}{|c|}{ Mahogany Snapper } \\
\hline & \multicolumn{3}{|c|}{ SEUS } & \multicolumn{2}{|c|}{ U.S. Caribbean } & \multicolumn{3}{|c|}{ SEUS } & \multicolumn{2}{|c|}{ U.S. Caribbean } \\
\hline & $\begin{array}{c}\text { SRHS } \\
\text { No. }\end{array}$ & $\begin{array}{l}\text { MRIP } \\
\text { No. }\end{array}$ & $\begin{array}{c}\text { Comm } \\
\mathrm{kg}\end{array}$ & $\begin{array}{c}\text { MRIP } \\
\text { No. }\end{array}$ & $\begin{array}{c}\text { Comm } \\
\mathrm{kg}\end{array}$ & $\begin{array}{c}\text { SRHS } \\
\text { No. }\end{array}$ & $\begin{array}{c}\text { MRIP } \\
\text { No. }\end{array}$ & $\begin{array}{c}\text { Comm } \\
\mathrm{kg}\end{array}$ & $\begin{array}{c}\text { MRIP } \\
\text { No. }\end{array}$ & $\begin{array}{c}\text { Comm } \\
\mathrm{kg}\end{array}$ \\
\hline 1981 & 8 & 3238 & & & & 9 & 8484 & & & \\
\hline 1982 & 7 & & & & & 42 & 2300 & & & \\
\hline 1983 & 21 & & & & & 12 & 824 & & & \\
\hline 1984 & 92 & 1169 & & & & 15 & 17048 & & & \\
\hline 1985 & 2 & & & & & 51 & 4065 & & & \\
\hline 1986 & 103 & 3946 & & & & 15 & & & & \\
\hline 1987 & 25 & & & & & 17 & & & & \\
\hline 1988 & 20 & & & & 31 & 34 & & & & 69 \\
\hline 1989 & 17 & & & & 5 & 6 & & & & 1482 \\
\hline 1990 & 86 & & & & & & & & & \\
\hline 1991 & 166 & & 113 & & 142 & 12 & & & & \\
\hline 1992 & 344 & & 150 & & 44 & 5 & & & & 34 \\
\hline 1993 & 181 & 1600 & 142 & & 270 & 9 & & & & 30 \\
\hline 1994 & 379 & & 115 & & 206 & 4 & & & & 62 \\
\hline 1995 & 265 & & 394 & & 30 & 19 & & & & 233 \\
\hline 1996 & 88 & 1227 & 894 & & 108 & 79 & & 35 & & 133 \\
\hline 1997 & 122 & & 926 & & 6 & 49 & & & & 569 \\
\hline 1998 & 144 & 1304 & 1012 & & & & & 44 & & 160 \\
\hline 1999 & 30 & 925 & 444 & & 45 & 198 & 2462 & & & 25 \\
\hline 2000 & 34 & 1687 & 385 & 7815 & 59 & & & & 2817 & 33 \\
\hline 2001 & 70 & 896 & 880 & 22067 & 1026 & & & & 928 & 5 \\
\hline 2002 & 56 & 318 & 488 & 17258 & 65 & & 643 & & & \\
\hline 2003 & 20 & 1415 & 875 & 4445 & 12 & & & & 2234 & 7 \\
\hline 2004 & 40 & 670 & 766 & 2542 & & & & & 651 & \\
\hline 2005 & 18 & 1895 & 314 & 1035 & & & & & & \\
\hline 2006 & 330 & 648 & 913 & 1771 & 33 & & & & & \\
\hline 2007 & 25 & 14364 & 540 & 18767 & 188 & & 1530 & & 704 & \\
\hline 2008 & 130 & & 518 & 4435 & 60 & 43 & & & & \\
\hline 2009 & 11 & 2759 & 518 & 12130 & & 22 & 176 & & 668 & 12 \\
\hline 2010 & 101 & 586 & 164 & 2307 & 10 & 23 & & & 455 & 9 \\
\hline 2011 & 34 & 325 & 330 & 3890 & 34 & & & & & 137 \\
\hline 2012 & 45 & 486 & 345 & 4694 & 29 & & & & & 586 \\
\hline 2013 & 51 & & 296 & 4798 & & 116 & & & & 718 \\
\hline 2014 & 24 & 28 & 249 & & & 176 & & & & 537 \\
\hline 2015 & 65 & 627 & & 7679 & & 184 & 595 & & 2243 & 2 \\
\hline$\sum$ & 3154 & 40113 & 11771 & 115633 & 2403 & 1140 & 38127 & 79 & 10700 & 4843 \\
\hline
\end{tabular}


508 Table 2. Number of otolith samples available for age-growth study of dog snapper and 509 mahogany snapper from the Southeastern U. S.

510

Dog Snapper

\begin{tabular}{lcccc}
\hline \multicolumn{5}{c}{ Dog Snapper } \\
\hline Fishery & Florida & N. Carolina & S. Carolina & Total \\
\hline Commercial & 26 & 5 & 1 & 32 \\
Recreational & 24 & - & - & 24 \\
Total & 50 & 5 & 1 & 56 \\
\hline & & Mahogany Snapper & Total \\
\hline Fishery & Florida & N. Carolina & S. Carolina & 10 \\
Commercial & 10 & - & - & 44 \\
Recreational & 44 & - & - & 54 \\
Total & 54 & - & - & \\
\hline \hline
\end{tabular}

511

512

513

514

515

516

517

518

519

520

521

522

523

524

525

526

527

528

529

530 
531 Table 3. Observed mean and predicted total length from size-limit corrected growth 532 model (TL, mm) of dog snapper (Lutjanus locu) and mahogany snapper (Lutjanus 533 mahogoni) collected from $1979-2015$ along the southeastern U. S. coast. 534

\begin{tabular}{rllrrrrlrr}
\hline \multicolumn{1}{c}{ Dog Snapper } \\
\hline Age & $n$ & Mean TL $( \pm$ SE) & TL Range & Pred. TL & Age & $n$ & Mean TL ( \pm SE) & TL Range & Pred. TL \\
\hline 2 & 6 & $298(24)$ & $200-351$ & 213 & 2 & 1 & 300 & & 210 \\
3 & 7 & $322(22)$ & $258-401$ & 310 & 3 & 1 & 270 & 243 \\
4 & 8 & $384(28)$ & $267-480$ & 389 & 4 & 1 & 325 & 267 \\
5 & 7 & $491(22)$ & $376-522$ & 453 & 5 & 3 & $308(13)$ & $285-330$ & 285 \\
6 & 6 & $505(36)$ & $334-575$ & 506 & 6 & 5 & $331(7)$ & $304-347$ & 298 \\
7 & 6 & $585(35)$ & $423-655$ & 550 & 7 & 5 & $330(7)$ & $307-346$ & 308 \\
8 & 2 & $483(143)$ & $340-626$ & 585 & 8 & 5 & $335(6)$ & $318-355$ & 315 \\
9 & 6 & $626(31)$ & $518-733$ & 615 & 9 & 5 & $342(8)$ & $322-367$ & 320 \\
10 & 2 & $704(17)$ & $687-720$ & 638 & 10 & 4 & $323(7)$ & $305-336$ & 324 \\
12 & 2 & $510(189)$ & $322-699$ & 674 & 11 & 5 & $350(12)$ & $320-380$ & 326 \\
13 & 1 & 755 & & 687 & 12 & 5 & $339(20)$ & $303-416$ & 328 \\
21 & 1 & 708 & & 734 & 13 & 4 & $337(20)$ & $307-359$ & 330 \\
22 & 1 & 763 & 736 & 14 & 5 & $360(14)$ & $330-407$ & 331 \\
33 & 1 & 837 & 745 & 15 & 2 & $341(0.5)$ & $341-342$ & 332 \\
& & & & 16 & 2 & $330(10)$ & $320-340$ & 332 \\
\hline \hline
\end{tabular}

535

536

537

538

539

540

541

542

543

544

545

546

547

548

549

550

551

552

553 
554 Table 4. von Bertalanffy parameters and associated statistics for dog snapper (Lutjanus 555 jocu) and Mahogany snapper (Lutjanus mahogoni) collected from the southeastern U. S. 556 from 1979 - 2015, with comparison to parameters from studies of dog snapper from other 557 areas.

558

\begin{tabular}{lcccccc}
\hline Study/Parameter & $\mathrm{L}_{\infty}$ & $\mathrm{SE}$ & $\mathrm{K}$ & $\mathrm{SE}$ & $\mathrm{t}_{0}$ & $\mathrm{SE}$ \\
\hline $\begin{array}{l}\text { Dog snapper - this study, freely } \\
\text { estimated }\end{array}$ & $783 \mathrm{TL}$ & 75 & 0.15 & 0.05 & -1.30 & 1.09 \\
$\begin{array}{l}\text { Dog snapper - this study, bias- } \\
\text { corrected }\end{array}$ & $746 \mathrm{TL}$ & 78 & 0.20 & 0.09 & 0.32 & 1.44 \\
$\begin{array}{l}\text { Dog snapper - Cuba (Claro, Sierra \& } \\
\text { Garcia-Arteaga, 1999) }\end{array}$ & $\begin{array}{c}\text { 854 FL } \\
(903 \mathrm{TL})\end{array}$ & & 0.10 & & -2.00 & \\
$\begin{array}{l}\text { Dog Snapper - Brazil (Rezende \& } \\
\begin{array}{l}\text { Ferreria, 2004) } \\
\text { (872 FL }\end{array}\end{array}$ & & 0.11 & & -3.73 & \\
$\begin{array}{l}\text { Dog snapper - Brazil (Previero et al., } \\
\text { 2011) }\end{array}$ & $878 \mathrm{FL}$ & & 0.10 & & -1.49 & \\
$\begin{array}{l}\text { Mahogany snapper - this study, } \\
\text { freely estimated }\end{array}$ & $346 \mathrm{TL}$ & 7 & 0.28 & 0.13 & -4.18 & 3.42 \\
$\begin{array}{l}\text { Mahogany snapper - this study, } \\
\text { bias-corrected }\end{array}$ & $334 \mathrm{TL}$ & 17 & 0.31 & 0.32 & -1.19 & 6.71 \\
\hline
\end{tabular}


572 Figure 1. Photographs of transverse sections of sagittal otoliths from a). dog snapper

573 (Lutjanus jocu), age 11, edge type 1 - 687 mm TL, captured 07/03/2015; b) dog snapper

574 (Lutjanus jocu), age 22, edge type 4 - 708 mm TL, captured 07/03/2012; c) mahogany

575 snapper (Lutjanus mahogoni), age 5, edge type 4 - 332 mm TL, captured 04/13/1999; d)

576 mahogany snapper (Lutjanus mahogoni), age 14, edge type 1 - $330 \mathrm{~mm}$ TL, captured $57707 / 01 / 2005$.

579 Figure 2. Frequency of edge type by month (marginal increment analysis) of a) dog 580 snapper (Lutjanus jocu) and b) mahogany snapper (Lutjanus mahogoni) otoliths from the 581 SEUS: Edge type 1 = opaque zone on edge; edge type 2 = narrow translucent zone on 582 edge $(<30 \%$ of previous translucent zone); edge type $3=$ moderate translucent zone on 583 edge (30\% - $60 \%$ of previous translucent zone); and edge type $4=$ wide translucent zone 584 on the edge ( $>60 \%$ of previous translucent zone). Numbers above each bar were the 585 sample size for each month.

587 Figure 3. Observed and predicted lengths-at-age for a) dog snapper (Lutjanus jocu) and 588 b) mahogany snapper (Lutjanus mahogoni), sampled from the southeastern United States 589 from $1979-2015$, measured in total lengths (TL). 
592 Figure 4. Scatter plot of whole weight - total length relationship for a) dog snapper

593 (Lutjanus jocu) and b) mahogany snapper (Lutjanus mahogoni) sampled from the

594 southeastern United States from 1979 - 2015.

595

596

597

598

599

600

601

602

603

604

605

606

607

608

609

610

611

612

613

614

615

616

617

618

619

620

621

622

623

624

625

626

627

628

629

630

631

632

633

b.

634 
a.
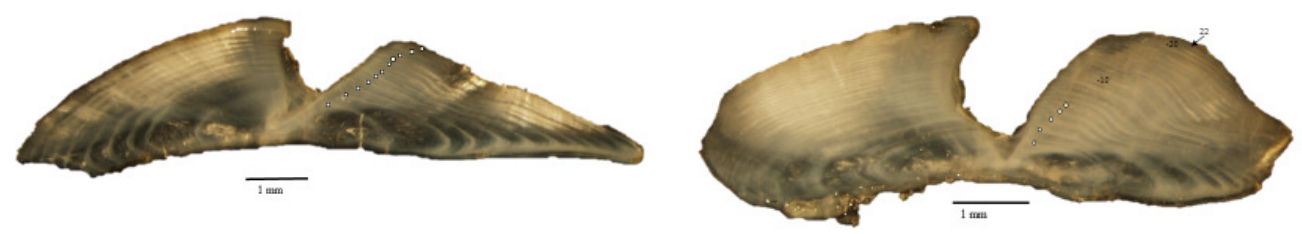

1
1
1

640

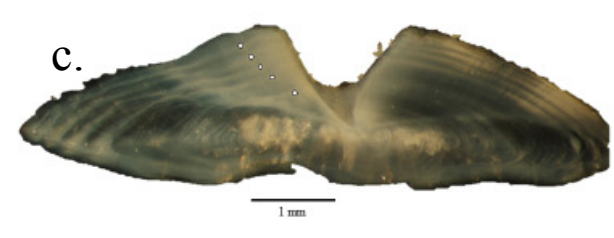

d.

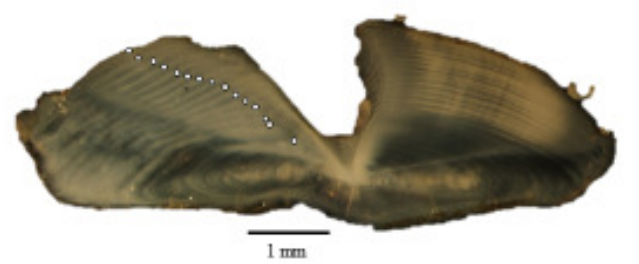

641

642

643

644

645

646

647

648

649

650

651

652

653

654

655

656

657

658

659

660

661

662

663

664

665

666 
667

668

669

a.

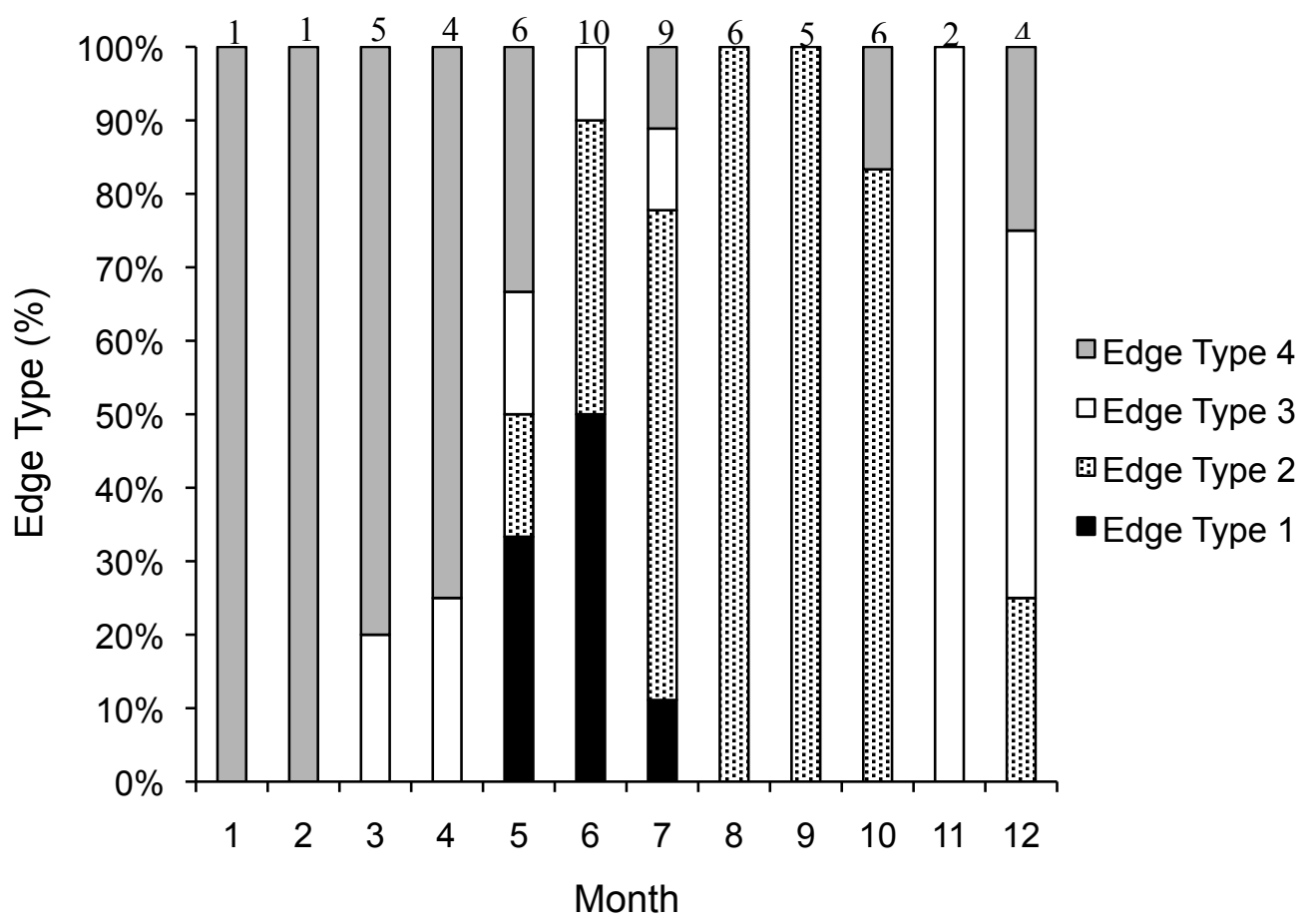

670

671

b.

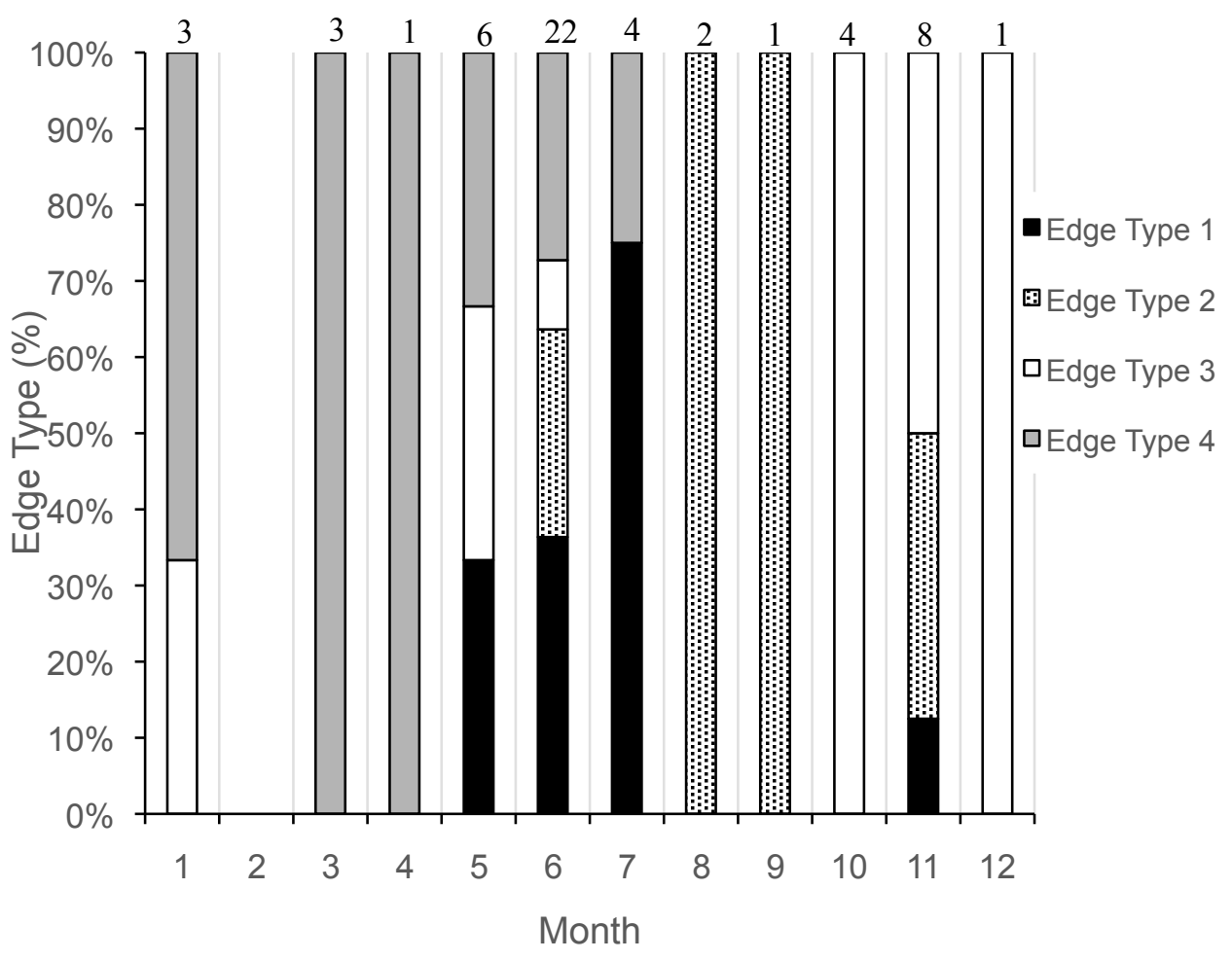


673

674 Figure 2

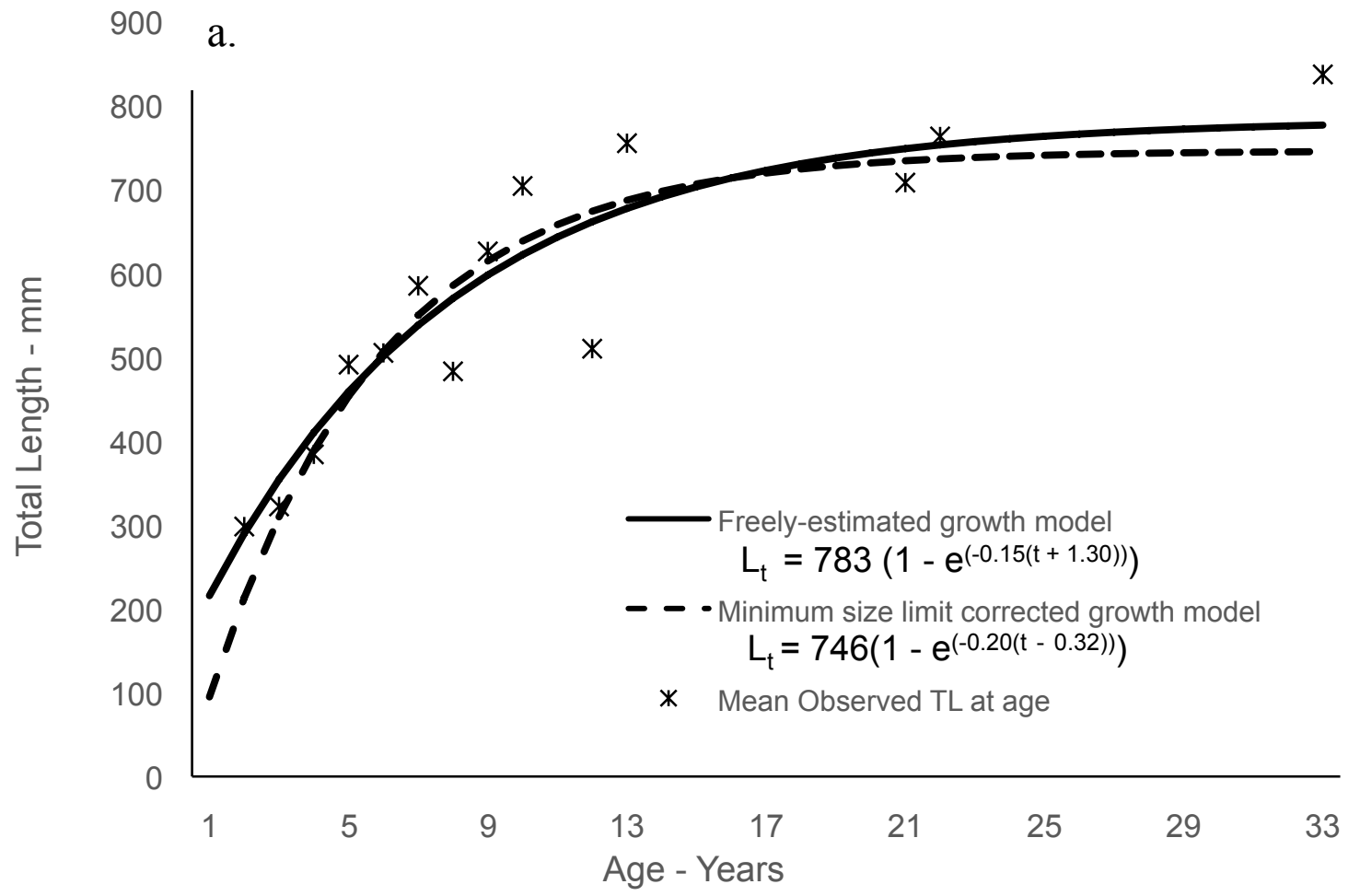

675 
b.

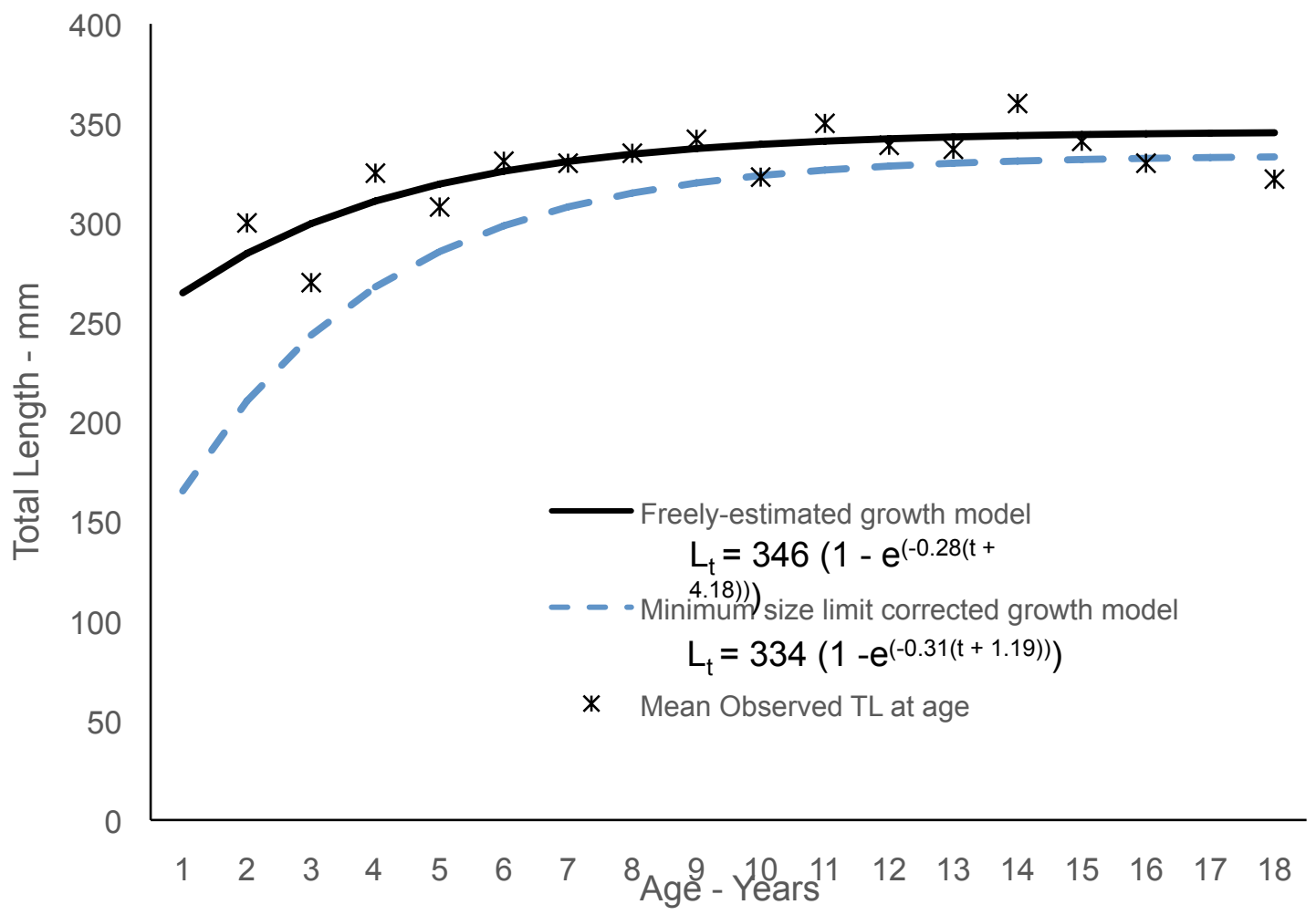

676

Figure 3 


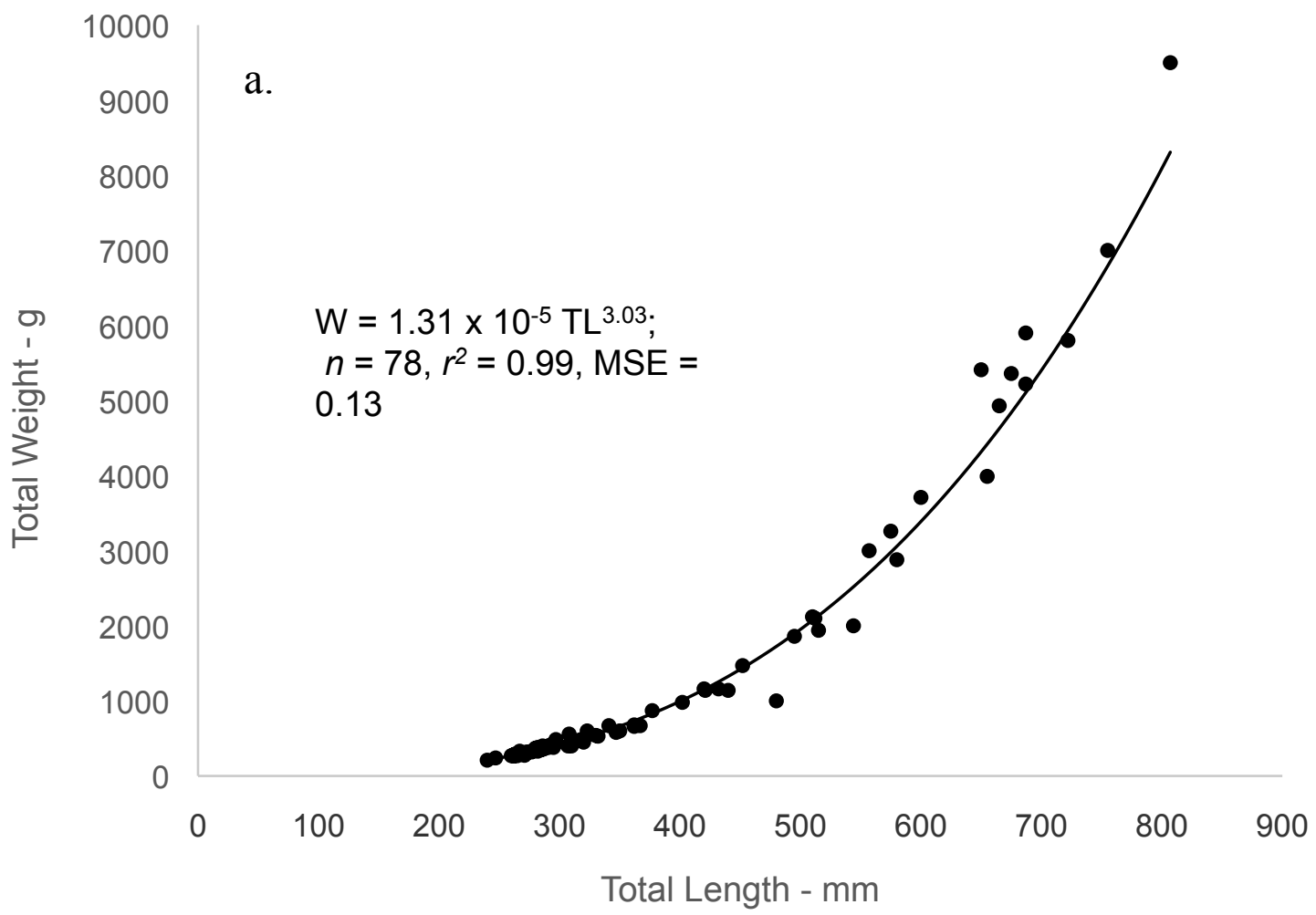

678

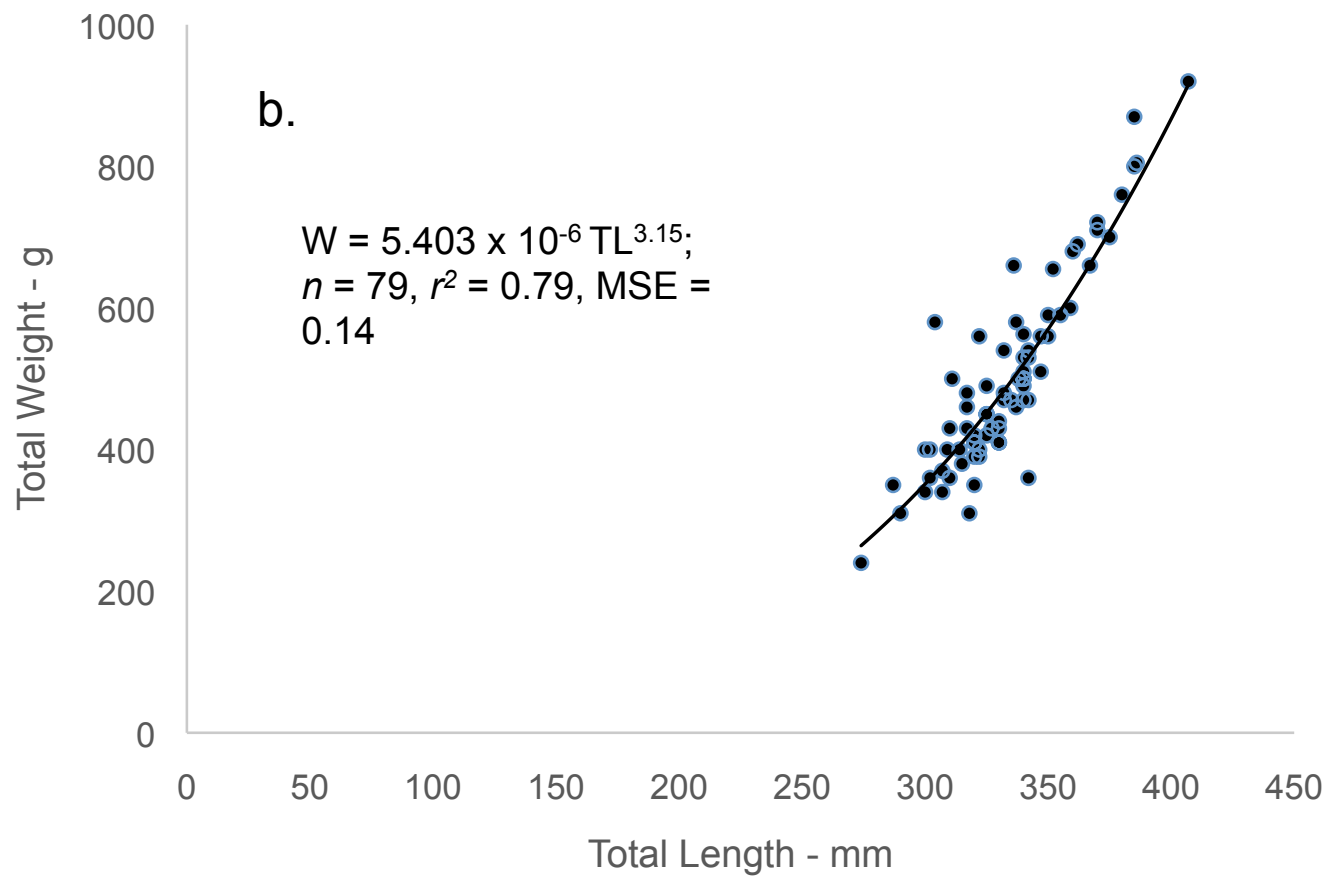

679

680 Figure 4 